\author{
Natalia Cybort-Zioło \\ Uniwersytet Szczeciński \\ E-MAL: natalia.cybort@gmail.com \\ Magdalena Mazur \\ Uniwersytet Szczeciński \\ E-MAL: magdalena.mazur.m@gmail.com
}

\title{
Pościelone łóżko. Rzeczy jako narzędzia oporu w bursie
}

\begin{abstract}
STRESZCZENIE
W artykule stawiamy tezę, że rzeczy, które znajdują się w bursach, mogą z jednej strony być wykorzystywane jako przejaw władzy nad wychowankami, a z drugiej stanowić dla wychowanków narzędzie oporu. Obecność rzeczy w regulaminach zachodniopomorskich burs i konteksty ich wykorzystania w tych dokumentach stanowią dla nas źródło informacji na temat roli i funkcji rzeczy w bursach. W artykule jednak próbujemy spojrzeć na zapisy regulaminów z perspektywy wychowanków, których obecność w bursach uwikłana jest w strukturę władzy i którzy posługują się rzeczami, aby wyrazić sprzeciw wobec zasad, których nie rozumieją lub nie przyjmują.
\end{abstract}

SŁOWA KLUCZOWE: pedagogika rzeczy, bursa szkolna, regulaminy burs

\section{Wprowadzenie}

Uwzględnienie roli rzeczy w refleksji nad wychowaniem skłania nas do rozszerzenia relacji wychowanek-wychowawca o dodatkowych „uczestników” tego procesu i otwiera nowe możliwości interpretacji praktyki edukacyjnej. Ze względu na badawcze zainteresowanie problematyką wychowania w bursach i internatach, przyjęcie perspektywy pedagogiki rzeczy skłoniło nas do namysłu nad tym, jaką rolę w procesie wychowania w bursach pełnią rzeczy, a w konsekwencji do postawienia pytania, czy rzeczy w bursach mogą stanowić narzędzie oporu. Jedną z wielu perspektyw ujmowania oporu jako przedmiotu badań jest perspektywa emancypacyjna (Bilińska-Suchanek, 2006, s. 18). Posłużyłyśmy się tą kategorią, aby podkreślić związek między codziennością wychowanków burs a panującymi w nich relacjami władzy. $\mathrm{W}$ bursach bowiem, podobnie jak w szkołach, mamy do czynienia z grupą dominującą i grupą podporządkowaną. Uświadomiony opór natomiast, który wynika z braku akceptacji dla określonego stanu rzeczy, zdaniem Marii 
Czerepaniak-Walczak, może doprowadzić do wykształcenia kompetencji emancypacyjnych (2006, s. 131-133).

Zaprezentowane $\mathrm{w}$ dalszej części artykułu tezy powstały w wyniku analizy regulaminów burs szkolnych zlokalizowanych w województwie zachodniopomorskim. Nasze działania badawcze skoncentrowałyśmy wokół regulaminów, ponieważ są one przez nas postrzegane jako oficjalne wykładnie definiowania relacji między ludźmi i rzeczami. Praktyka pedagogiczna oraz systematyczna obserwacja codzienności w bursie podczas pracy zawodowej na stanowisku nauczyciela-wychowawcy pozwoliła nam na wyłonienie pytań problemowych, które stały się początkiem naszych badawczych poszukiwań, a pytania o to, jaka jest rola rzeczy w procesie wychowania w świetle zapisów regulaminów burs szkolnych z województwa zachodniopomorskiego oraz w jaki sposób wychowankowie tych burs odnoszą się do zapisów regulaminów, które dotyczą rzeczy, zapoczątkowały opisy określonego wycinka instytucjonalnej rzeczywistości.

$\mathrm{W}$ badaniu w celu zgromadzenia informacji o rzeczach występujących w regulaminach zachodniopomorskich burs zastosowałyśmy technikę analizy treści. W ten sposób poddałyśmy ilościowej analizie regulaminy wszystkich burs szkolnych w województwie zachodniopomorskim, które udostępniały je na swoich stronach internetowych. Łącznie było to dziewięć burs. Zebrany materiał kodowałyśmy posługując się przygotowanym przez nas narzędziem, pozwalającym na wyróżnienie interesujących nas kategorii. Następnie dokonałyśmy analizy porównawczej zebranego materiału. Analiza przeprowadzona została we wrześniu 2017 roku. W artykule wykorzystane zostały ponadto własne spostrzeżenia, wynikające z pracy zawodowej w bursie, które pozwoliły nam odnieść się do zapisów regulaminu.

Prezentowana analiza jest próbą odniesienia przyjętej perspektywy pedagogiki rzeczy do myślenia o praktyce edukacyjnej. Celem artykułu jest przedstawienie wybranych sposobów wyrażania oporu wychowanków bursy za pośrednictwem rzeczy znajdujących się w placówce.

\section{Rzeczy jako narzędzia oporu}

Rzeczy rozumiane są przez nas w tym artykule zarówno w aspekcie fizycznym, zgodnie z ich definicją słownikową jako „materialny element otaczającego świata; przedmiot będący czyjąś własnością" ${ }^{1}$, jednak ich rolę postrzegamy szerzej, jako elementy świata społecznego, które aktywnie uczestniczą

1 Słownik języka polskiego PWN, https://sjp.pwn.pl/szukaj/rzeczy.html [dostęp online: 07.10.2017], również „filoz. cokolwiek, co może być przedmiotem postrzeżenia zmysłowego, ma właściwości przestrzenne, trwa w czasie i czemu przypisujemy byt od nas niezależny; też: cokolwiek, co może być przedmiotem sądu”. 
w procesach społecznych, w tym procesach wychowania. Odwołujemy się tym samym do koncepcji, nazwanej przez Maksymiliana Chutorańskiego i Anetę Makowską pedagogiką rzeczy, która stanowi

próbę nazwania tych wysiłków badawczych, które skupiają się na rozumieniu zarówno znaczeń nadawanych rzeczom w procesach edukacyjnych, jak i opisowi związków ludzi oraz rzeczy, a także rekonstrukcji dynamicznych relacji między ludzkimi i pozaludzkimi aktorami procesów edukacyjnych i kulturowych; edukacyjnych relacji między tym, co ludzkie i pozaludzkie (2019, s. 12).

Opisując rolę rzeczy występujących w regulaminach burs w odniesieniu do ich relacji z wychowankami i wychowawcami burs, lokujemy swoją analizę w drugim z trzech proponowanych przez Chutorańskiego i Makowską sposobów problematyzowania zagadnień mieszczących się w obrębie pedagogiki rzeczy, a mianowicie rekonstrukcji relacji ludzi i rzeczy w niewielkim polu interakcji edukacyjnych $^{2}$. Na tej płaszczyźnie, dokonując analizy regulaminów, stawiamy pytania, w jaki sposób rzeczy są wykorzystywane do budowania relacji władzy w procesach wychowawczych w bursach. Przywołane w tekście przykłady działań podejmowanych przez wychowanków pozwalają nam natomiast pokazać, w jaki sposób rzeczy mogą stać się narzędziem negocjowania tych relacji. Zdaniem przywołanych badaczy bowiem „rzeczy nie zawsze naszym działaniom się poddają, mogą je wspierać, ale równie dobrze stawiać im opór, negocjować i zmieniać relacje, w które wchodzą" (Chutorański, Makowska, 2016, s. 66-78).

Regulaminy stanowią wbursach narzędzie narzucania wychowankom określonych norm zachowania, których egzekutorami są głównie wychowawcy. Za pośrednictwem tych aktów, a także $\mathrm{w}$ codziennych interakcjach $\mathrm{z}$ wychowankami, podejmują oni działania w celu wyegzekwowania od wychowanków określonych postaw czy zachowań. Często są to postawy lub zachowania wobec rzeczy. Stają one tym samym w centrum interakcji pomiędzy reprezentantami kultury dominującej (wychowawcy) i podporządkowanej (wychowankowie), której nieodłącznym elementem są zachowania oporowe.

Peter McLaren wyróżnił cztery stany interakcji uczniów ze środowiskiem oraz innymi ludźmi, charakteryzujące się odmiennymi typami zachowań: stan ulicy/pozaszkolny (the streetcornerstate), stan uczniowski/szkolny (the student state), stan podniosły (the sancitystate) i stan domowy (the homestate) (McLaren, 1999, s. 85-93). W bursach szkolnych wszystkie te typy interakcji

2 Dwie pozostałe perspektywy związane są z rekonstrukcją znaczeń nadawanych rzeczom w interakcjach edukacyjnych i podejmowanych w związku z tą relacją działań oraz odniesienie zagadnień mieszczących się w obrębie pedagogiki rzeczy do teorii relacyjnych i perspektywy antropocentrycznej (por. Chutorański, Makowska, 2019, s. 13-15). 
mieszają się ze sobą: z jednej strony promowany w niej, również za pośrednictwem regulaminów, model, jest odpowiednikiem wyróżnionego przez McLarena stanu szkolnego, $\mathrm{z}$ drugiej natomiast jest to miejsce, w którym wychowankowie wiodą swoje codzienne życie, a więc znajdują się w stanie pozaszkolnym. Opór wychowanków może więc wynikać z niezgody na kulturę dominującą, sposoby sprawowania władzy, ale też przewagę stanu szkolnego nad innymi, naturalnymi dla wychowanków stanami.

\section{Bursy i internaty w Polsce}

Według Encyklopedii pedagogicznej pod redakcją Wojciecha Pomykały wyraz bursa

w łacinie średniowiecznej oznaczał on dom (zakupiony lub zbudowany przez fundatora), w którym zamieszkiwała młodzież przybywająca do szkół w celu pobierania nauki. Zatem pod pojęciem bursy rozumiano początkowo najczęściej wspólne mieszkanie, na utrzymanie którego środki czerpano ze wspólnej kasy. W języku francuskim la bourse znaczy między innymi bezpłatne utrzymanie ucznia w kolegium i zasiłek pieniężny otrzymywany przez niego od władz, szkolnych lub z zapisu stypendialnego (1996, s. 265).

Według raportu Narodowej Izby Kontroli bursa natomiast to

rodzaj publicznej lub niepublicznej placówki zapewniającej opiekę i wychowanie uczniom w okresie pobierania nauki poza miejscem stałego zamieszkania, o której mowa w art. 2 pkt 7 ustawy o systemie oświaty. Zapewnia opiekę i wychowanie uczniom (słuchaczom) w wieku do 24. roku życia (Organizacja pobytu..., 2016, s. 4).

Mieszkańcami burs, zgodnie z przytoczonymi definicjami, jest młodzież. Okres adolescencji natomiast, zgodnie z teorią rozwoju Erika H. Eriksona, to czas, w którym kształtuje się ich tożsamość (2004, s. 83). Jest to szczególny dla rozwoju młodego człowieka okres, łączący wczesne dzieciństwo z późniejszymi stadiami (s. 87). Radykalne pozbawianie młodzieży w tym okresie form ekspresji może prowadzić, zdaniem Eriksona, do silnego oporu ze strony adolescentów, który z perspektywy tego specyficznego okresu jest uzasadniony (s. 85).

Problematyka burs (i internatów szkolnych), choć w ostatnim czasie cieszy się większym zainteresowaniem, nie jest jeszcze dobrze rozpoznana przez badaczy w Polsce. Znane nam aktualne publikacje dotyczące tej tematyki to w większości artykuły, fragmentarycznie podejmujące to zagadnienie.

Jedną ze współczesnych badaczek zajmujących się tematyką burs i internatów jest Marzena Okrasa (2017, 2005, s. 79-102), która w 2017 roku wydała publikację pod tytułem Bursy i internaty szkolne w województwie lubelskim w latach 1918-1998. Ponadto autorką licznych publikacji na temat burs i in- 
ternatów, w tym opublikowanej w 2011 roku książki Internat i bursa. Historia i współczesność, jest Beata Zięba-Kołodziej (2010, 2011). Wymieniona pozycja jest jedną z nielicznych nowych książek na ten temat, która jest szczególnie warta zainteresowania ze względu na uwzględnienie zarówno historii powstania burs i internatów, jak i ich współczesnej kondycji.

Ponadto badacze, którzy mieli znaczący wkład w badania związane z bursami i internatami, to m.in. Zbigniew Węgierski (1979), Józefa Brągiel (1982), Aleksander Makowski (1988) czy Krystyna Kowalik (1975). Publikacje tych autorów stanowią istotne podwaliny do badań nad współczesnymi bursami i internatami, i choć ukazywały się w latach 1975-1998, wciąż często stanowią punkt odniesienia w aktualnych opracowaniach.

Poznane przez nas opinie wychowanków na temat ich codziennego życia w bursach ujawniły wiele kategorii świadczących o doświadczaniu przez młodzież opresji, która wynika przede wszystkich z obowiązujących w bursach reguł, których nośnikiem są regulaminy. Często, z braku innych możliwych dróg wyzwolenia spod tej opresji, wychowankowie wyrażają swój opór wobec postanowień przyjętych (odgórnie) w regulaminach poprzez łamanie punktów jego postanowień. W naszym artykule skupiamy się na sposobach wyrażania oporu przez młodych ludzi w odniesieniu do rzeczy.

\section{Rzeczy w regulaminach burs}

Posługując się wykazem szkół i placówek z terenu województwa zachodniopomorskiego (stan na 31.03.2017 r.), zamieszczonego na stronie internetowej Kuratorium Oświaty w Szczecinie ${ }^{3}$, wyłoniłyśmy wszystkie bursy szkolne, których siedziba znajduje się w województwie zachodniopomorskim, a następnie dokonałyśmy analizy regulaminów tych burs, które udostępniały je na swojej stronie internetowej.

Analizując regulaminy burs, zastosowałyśmy skonstruowane przez nas na potrzeby niniejszej analizy narzędzie. Każdą z rzeczy wymienionych w regulaminie opisywałyśmy w następujących kategoriach: lokalizacja, cechy, dział regulaminu, dokładny zapis regulaminu. Z uwagi na odmienne sposoby nazywania określonych rzeczy w regulaminach, po opisaniu w ten sposób każdej rzeczy pogrupowałyśmy je dodatkowo na kategorie. Najliczniejsze z nich to: kategoria ogólne ${ }^{4}$, używki, meble, elektronika, klucz, okna, pościel,

3 Kuratorium Oświaty w Szczecinie, Wykaz szkół i placówek, http://www.kuratorium.szczecin.pl/zalaczniki/wykaz_szkol.xls [dostęp online: 31.03.2017]; placówki, których regulaminy zostały objęte naszą analizą to: Bursa Szkolna Integracyjna, ul. Zygmunta Starego 1, Bursa Towarzystwa Salezjańskiego, ul. Ku Słońcu 124, Bursa Szkolna nr 2, ul. Pokoju 48.

4 Dotyczy grup rzeczy nazwanych ogólnym określeniem, np. urządzenia, przedmioty, mienie. 
AGD, jedzenie, instalacje, odzież i obuwie, urządzenia grzewcze, inne. Kategorie te nie stanowią jednorodnego zbioru $\mathrm{z}$ uwagi na przyjęte $\mathrm{w}$ tym artykule szerokie rozumienie rzeczy, a także z uwagi na to, że zostały one wyłonione dopiero z zebranego materiału badawczego. W każdej kategorii, która obejmowała więcej niż jedną rzecz, wyróżniłyśmy ponadto rzeczy, które w regulaminach występowały najczęściej 5 . Analiza porównawcza tak skategoryzowanego materiału pozwoliła nam na wyłonienie rzeczy, które w regulaminach burs powtarzają się najczęściej. Spośród nich w tym artykule opiszemy tylko te, które według regulaminów umieszczone są w pokoju wychowanka.

W tym miejscu wart zaznaczenia jest fakt, że regulaminy, które zostały poddane przez nas analizie, $\mathrm{w}$ wielu miejscach podobne są do regulaminów z pierwszej połowy XX wieku. W kontekście historii powstawania burs i internatów (te początkowo były głównie miejscami ściśle związanymi z wychowaniem zakonnym, co wiązało się z określonymi, rygorystycznymi zasadami oraz dyscypliną), pomimo upływu lat, można odnaleźć analogie do współcześnie formułowanych regulaminów, głównie w zapisach dotyczących obowiązków i praw mieszkańców bursy, czy godzinowym rozkładzie dnia (por. Zięba-Kołodziej, 2011, zał. nr 2, s. 124-127). Może to oznaczać, że nieaktualizowane regulaminy lub te bazujące na regulaminach $\mathrm{z}$ historycznych początków burs (czego prawdopodobnie nie zawsze są świadomi ich autorzy), mogą nie być adekwatne do współczesnych, zmieniających się realiów życia młodych mieszkańców burs i internatów. Ponadto regulaminy, które nie są uaktualniane, nie uwzględniają pojawiających się wraz z zachodzącymi przemianami społecznymi wyzwań.

W przeanalizowanych przez nas regulaminach poświęca się wiele miejsca rzeczom. Są one istotnym odniesieniem dla twórców regulaminów. Rzeczy występują w niemal wszystkich działach, w analizowanych regulaminach najczęściej natomiast ujmowane są w kontekście zakazów (użytkowania jakiejś rzeczy) lub nakazu (użytkowania rzeczy w określony sposób).

\section{Przede wszystkim: czystość i porządek!}

Wychowanek bursy ma obowiązek: Utrzymywać porządek, czystość, estetykę pomieszczeń mieszkalnych (staranne ścielenie tapczanu, przechowywanie w nim tylko pościeli i bielizny nocnej, utrzymanie porządku i czystości w szafach ubraniowych, szafkach i szafach nocnych, wietrzenie pomieszczeń) i pomieszczeń wspólnego użytku oraz otoczenia bursy (Regulamin A).

5 Przykładowo w kategorii „ogólne” były to: urządzenia, sprzęt, mienie, rzeczy, przedmioty. W kategorii „meble”: meble, szafa, szafka, tapczan/łóżko. 
We wszystkich analizowanych regulaminach wychowanek ma obowiązek utrzymywać porządek, czystość i estetykę swojego pokoju, a zalecenia te występują głównie w powiązaniu z rzeczami. Weryfikowanie przestrzegania tego punktu regulaminu dokonuje się przede wszystkim podczas cotygodniowych „komisji czystości”, w skład których wchodzą zarówno wychowawcy, jak i wychowankowie. „Komisje czystości” odbywają się raz w tygodniu o określonej porze i polegają na ocenie każdego pokoju według ustalonych wcześniej kategorii (np. stopień zapełnienia kosza na śmieci lub usunięcia kurzu z szafek). Dla części mieszkańców bursy taki sposób sprawdzania poziomu czystości w ich pokoju wydaje się niesprawiedliwy, ze względu np. na odbywające się tego dnia zajęcia pozalekcyjne, konieczność przygotowania do sprawdzianów, sympatie i antypatie członków komisji. W konsekwencji stosują pierwszy z prezentowanych w tym artykule przejawów oporu: otwarcie porządkują pokój wyłącznie na czas komisji i przestają dbać o porządek zaraz po jej zakończeniu. Komisja natomiast wydaje się mieć za zadanie pilnowanie, by te określone rzeczy były wyeksponowane i widoczne dla osób odwiedzających pokój. Jedynie pozornie sprawdza, czy w pokoju faktycznie jest utrzymywana czystość. Można powiedzieć, że komisje są materialnym przedłużeniem władzy nad umysłami młodzieży - one też powinny być poukładane, dobrze się prezentować i postępować zgodnie z ustaleniami.

$\mathrm{W}$ innym zapisie występującym w regulaminach wychowanek może dekorować swój pokój wyłącznie za zgodą kierownika bursy (Regulamin A). W dosłownym brzmieniu zapisów regulaminowych tego zakazu brakuje doprecyzowania określenia „dekorowanie”. O ile możliwe do uzasadnienia może być ograniczenie możliwości dekorowania w przypadku trwałej ingerencji w ściany (np. wiercenia w nich), o tyle za dekorowanie można uznać również postawienie na szafce ramki ze zdjęciem. Formułowanie zapisów w podobny sposób nie jest jasne i pozostawia duże pole decyzyjności w poszczególnych przypadkach wychowawcy.

Zakazane na podstawie tego zapisu mogą być wszelkie formy zagospodarowania przestrzeni pokoju w bursie, które wychodzą poza schemat zastanego układu mebli, koloru ścian oraz innych elementów wystroju. Pokój wychowanka stanowi miejsce jego życia, jest namiastką jego własnego pokoju, miejsca, w którym czuje się sobą i może w nim realizować swoje prawo do autoekspresji, które powinno uczyć go wyrażania własnych myśli i poglądów, a także poszanowania autoekspresji innych (Babicka-Wirkus, 2015, s. 66).

$\mathrm{Z}$ naszych obserwacji wynika, że odpowiedzią na nieposzanowanie tego prawa są reakcje oporowe wychowanków, którzy samodzielnie przyklejają do ścian plakaty, zdjęcia, czy notatki, do momentu, w którym nie zostanie 
zwrócona im uwaga. Rola dekorowania pokoju może być szczególnie ważna w kontekście oporu, ponieważ w znaczących elementach oporu chodzi szczególnie o takie doświadczenia, w których młodzi ludzie mogą zabrać głos, wyrazić siebie. W skrajnym, jednym przypadku, w regulaminie wystąpił zapis, według którego w pokoju można posiadać tylko niezbędne przedmioty do nauki i codziennego życia (Regulamin B).

\section{Sprzęt}

We wszystkich analizowanych regulaminach znajduje się zapis, że mieszkańcy poszczególnych pokojów, choć samodzielnie nie są uprawnieni do podejmowania decyzji dotyczących chociażby wspomnianego już dekorowania pokoju, mogą ponieść odpowiedzialność za zniszczenie znajdującego się w nim sprzętu. Według Słownika języka polskiego PWN sprzęt to „przedmiot użytkowy” (2006, s. 949) lub w drugim znaczeniu są to "przedmioty używane do jakichś prac lub w jakichś okolicznościach” (s. 949). Odpowiedzialność za sprzęt należałoby potraktować w tym ujęciu jako odpowiedzialność prawną (Marek, 2009, s. 24), regulowaną przez obowiązujące nakazy i zakazy, których niespełnienie odczytywane jest jako zawinienie podlegające karze. Jeśli więc zapis ten odnosi się wyłącznie do odpowiedzialności materialnej, to niejasne są kryteria ponoszenia tej odpowiedzialności, np. o jakie zniszczenia sprzętu chodzi? Czy również te, które wynikają z jego poprawnego użytkowania?

Ponadto odpowiedzialność za sprzęt nie jest w regulaminach burs jednakowa dla placówki i wychowanków. Podobnie jak we wszystkich regulaminach pojawia się zapis o odpowiedzialności wychowanka za sprzęt w bursie, tak we wszystkich również zamieszczony jest zapis, że bursa nie ponosi odpowiedzialności za sprzęt wychowanka. Ta asymetria oddaje nierówność pomiędzy wychowankami a wychowawcami. Bursa szkolna, mimo że jako instytucja oświatowa zobowiązana jest do przestrzegania praw człowieka, narusza w ten sposób artykuł 7. Powszechnej Deklaracji Praw Człowieka, który brzmi: „wszyscy są równi wobec prawa i mają prawo, bez jakiejkolwiek różnicy, do jednakowej ochrony prawnej”. W ten sposób, zamiast wykorzystać wychowawczą funkcję bursy do kształtowania postaw odpowiedzialności, podkreśla się jej hierarchiczność i podległą rolę wychowanka.

\section{Urządzenia}

Drugą klasą rzeczy występującą w regulaminach są urządzenia. Wychowanek według zapisów analizowanych regulaminów ma prawo do korzystania z tych $\mathrm{z}$ nich, które są pomocne w procesie uczenia się i samorozwoju. W przypadku urządzeń elektrycznych jest dodatkowo zobowiązany do wyłą- 
czenia ich z kontaktu przed wyjazdem. Nie może jednak posiadać urządzeń elektrycznych w pokoju (poza jednym z regulaminów, według którego wychowanek może posiadać jeden czajnik elektryczny (Regulamin C)).

Możliwość posiadania w pokoju sprzętów AGD, głównie czajnika elektrycznego, jest dla wychowanków bursy istotną kwestią ze względu m.in. na późne chodzenie spać i ograniczone czasowo możliwości korzystania ze wspólnych pomieszczeń przeznaczonych do przygotowywania posiłków. $Z$ naszych obserwacji wynika, że wychowankowie czasem w odpowiedzi chowają urządzenia AGD (zwykle czajniki elektryczne i tostery) w tapczanie, na półkach z ubraniami i wykorzystują nie tylko zgodnie $\mathrm{z}$ ich pierwotnym przeznaczeniem, ale też np. do przygotowywania parówek lub makaronu. Wychowankowie są w stanie przechowywać w ten sposób urządzenia AGD, mimo że zapobiec temu mają zarówno zapisy regulaminu dotyczące bezpieczeństwa, jak i czystości, a także przepisy przeciwpożarowe i bezpieczeństwa i higieny pracy, z którymi wychowankowie powinni być zapoznawani już we wrześniu. $\mathrm{W}$ ten sposób obnażają ich nieskuteczność. Metody ukrywania czajników elektrycznych czy tosterów, a także kreatywne sposoby ich wykorzystywania są ponadto dla wychowanków często okazją do integracji w grupie rówieśniczej, a także demaskowania słabości mechanizmów wychowawczej kontroli.

\section{Drzwi, okna, parapety, szafy}

Wiele zapisów w analizowanych regulaminach dotyczyło drzwi - przede wszystkim drzwi do pokoi wychowanków. W zależności od bursy sprecyzowane są zasady z nimi związane, dla przykładu w regulaminie jednej z burs w ogóle o zamykaniu drzwi na klucz się nie pisze (jedynie, że wychowanek ma obowiązek pozostawić je otwarte w przypadku ewakuacji (Regulamin B)). Inny regulamin zawiera zapis, że ze względu na bezpieczeństwo wychowankowie nie mogą zamykać się w pokojach: „Zabronione jest zamykanie się w wewnątrz pokoju na klucz" (Regulamin C).

28. Wychodząc z pokoju należy zamykać go na klucz - każdy wychowanek posiada klucz do pokoju, który dorabia na własny koszt. Na koniec roku szkolnego klucz zdaje wychowawcy razem z kluczami od osobistych szafek (Regulamin C).

Trzeci natomiast regulamin precyzuje, że wychowanek nie może samodzielnie pobierać kluczy (bez wyraźnej zgody wychowawcy), jednocześnie nie posiadając własnego klucza do pokoju (Regulamin A). W przypadku tak sformułowanych zapisów wychowankowie wyrażają swoją niezgodę i opór wobec pozbawiania ich poczucia prywatności poprzez zakaz zamykania przez nich pokojów na klucz, samowolne pobieranie kluczy bez zgody wychowawców. 
W regulaminach najczęściej pojawiające się zapisy dotyczące okien (i parapetów), to te zakazujące czynności z nimi związanych. Zabrania się więc wychowankom przede wszystkim wychylać przez okna, ale też wyrzucać przez nie rzeczy. Na parapetach natomiast zabrania się przede wszystkim siadania, ale też wystawiania na nich produktów spożywczych.

Wszystkie regulaminy zawierają zapis, że wychowanek ma obowiązek utrzymywać w szafach (i na szafkach) porządek i czystość. To kontynuacja zapisu o konieczności utrzymywania porządku i estetyki w pokojach wychowanków.

Wychowanek ma obowiązek: (...) utrzymywać porządek w szafie z ubraniami, szafkach i biurku (Regulamin A).

Weryfikowanie tego punktu regulaminu wymagałoby jednak sprawdzania wnętrza mebli, w których wychowankowie trzymają prywatne rzeczy. To natomiast budzi kontrowersje wśród mieszkańców bursy, którzy obawiają się o swoje prawo do prywatności, tym bardziej, że inny zapis w jednym $\mathrm{z}$ regulaminów mówi, że wychowawca ma prawo w uzasadnionych przypadkach sprawdzić porządek i czystość w szafkach pod nieobecność wychowanka (Regulanin A). Ponadto użyty w zapisie zwrot „uzasadniony przypadek" nie jest zdefiniowany w regulaminie. Z naszych obserwacji wynika, że wychowankowie przechowują w szafach brudne talerze, resztki jedzenia, fermentujące napoje, obuwie (pomimo oddzielnego pomieszczenia do jego przechowywania).

Ponadto $\mathrm{w}$ regulaminach znajdują się zapisy o obowiązku ścierania kurzu z mebli, co istotne: codziennie. Wymóg ten rodzi pytanie o zasadność uwzględniania tego rodzaju zapisów w regulaminie, ponieważ trudno w tym przypadku wciąż mówić o trosce o warunki sanitarne, w których żyją mieszkańcy pokojów, a raczej o zapewnieniu wychowawcom narzędzi do dyscyplinowania młodzieży i wychowywania jej do podporządkowania regułom, które nie mają racjonalnego uzasadnienia.

\section{Lampki, śmieci}

We wszystkich analizowanych regulaminach występuje zapis, że wychowankowie mogą korzystać z lampek po godz. 22.00 (zamiast światła górnego). Jednocześnie, mimo że bursa ich nie zapewnia, zdarza się, że są zobowiązani do ich posiadania. Możliwość włączania górnego światła jest szczególnie istotna dla wychowanków ze względu na uczenie się w godzinach nocnych, dlatego stosują różne strategie unikania gaszenia światła po godz. 22.00. Znają zwyczaje wychowawców i na przykład gaszą górne światło tylko 
do czasu kontroli wychowawcy, po której je ponownie włączają. Z naszych obserwacji wynika, że czasem dodatkowo, aby uniknąć ponownej wizyty wychowawcy, zatykają szczelinę pomiędzy drzwiami a podłogą, aby światło było mniej widoczne.

Wychowankowie zobowiązani są również do codziennego wynoszenia śmieci, co w praktyce oznacza obowiązek wynoszenia śmieci każdego poranka, niezależnie od stopnia zapełnienia kosza.

Wychowanek ma obowiązek: (...) opróżniać kosz i myć go, śmieci z kosza w pokoju wynosić codziennie do pojemnika na podwórzu (Regulamin C).

Dodatkowo, czystość w koszu na śmieci weryfikowana jest przez komisje czystości, które odbywają się raz w tygodniu. Podczas inspekcji komisji wychowankowie wkładają pusty worek na worek lekko zapełniony, by wyglądało, jakby był pusty lub chowają śmieci do szafy, do której wychowawca nie zagląda.

Wychowanek ma obowiązek starannie ścielić tapczan (codziennie) i przechowywać w nim tylko pościel i bieliznę nocną. Wychowawcy kontrolują czystość w tapczanach podczas komisji czystości - zwracają uwagę w przypadku przechowywania w łóżkach rzeczy innych niż wymienione w regulaminie (bielizna nocna i pościel). Nie sprawdzają natomiast, co kryje się pod pościelą. Skrzynia łóżka jest dla młodzieży dodatkową przestrzenią do przechowywania - chowają w niej także inne rzeczy niż wymienione w regulaminie. Podczas komisji czystości układają więc pościel w skrzyni tak, by przykryć rzeczy, których tam nie powinno być. Jest to przestrzeń bardzo intymna dla młodzieży (często przechowują w niej np. brudne ubrania).

Starannie pościelone łóżko jest jednym z wielu zapisów, który ze względu na możliwość ich subiektywnego odczytywania wywołuje spory. Co bowiem oznacza określenie „starannie pościelone łóżko”? Różnice istnieją już w samych zapisach regulaminów poszczególnych burs:

Wychowanek bursy ma obowiązek: Utrzymywać porządek, czystość, estetykę pomieszczeń mieszkalnych (staranne ścielenie tapczanu, przechowywanie w nim tylko pościeli i bielizny nocnej (...) (Regulamin A).

Wychowanek ma obowiązek: Utrzymywać czystość i dbać o estetykę pokoju mieszkalnego: (...) codziennie starannie ścielić tapczan/łóżko, chować pościel do pojemnika (Regulamin C).

W piątek, przed opuszczeniem bursy, należy pozostawić porządek w pokojach (...) na tapczanie pozostawić poduszkę i złożoną kołdrę jeśli są własnością bursy (...) (Regulamin B). 
Interpretacja zapisów dotyczących ścielenia łóżka różni się zarówno w odniesieniu do różnych placówek, jak też poszczególnych wychowawców, czy wreszcie wychowanków. Nie dla wszystkich bowiem „starannie pościelone łóżko" to łóżko, na którym leży jedynie koc, a pościel schowana jest w skrzyni łóżka - jest to tylko jedna z obowiązujących konfiguracji i sposobów „starannego ścielenia", które egzekwowane są od wychowanków. Wychowanek, który nie pozostawia łóżka w powyższy sposób może zostać rano zatrzymany w bursie w celu jego uporządkowania (nawet kosztem spóźnienia się do szkoły). Zgodnie ze swoimi przyzwyczajeniami niektórzy wychowankowie ścielą łóżka, chowając koc, bądź pozostawiając elementy pościeli pod kocem, nie zwracając uwagi na zalecenia wychowawców. Wyrażają niezadowolenie, gdy zostaje im o poranku zwrócona uwaga na niepoprawnie lub niezaścielone łóżko, nie wyrażają zgody na zatrzymywanie ich w bursie z tego powodu.

\section{Podsumowanie}

Przedstawione $\mathrm{w}$ artykule przykłady istotnych w relacji wychowawczej w bursie rzeczy oraz ich roli w relacjach władzy i oporu to tylko zasygnalizowanie możliwych kontekstów interpretowania obecności rzeczy w procesie wychowania.

Negocjowanie zasad przez wychowanków jest trudne, a czasem nawet niemożliwe. Formalnie ustanowione prawo do negocjacji zapisów regulaminu i konieczności jego akceptacji przez mieszkańców bursy jest pozorne, a narzucane regulaminy jako narzędzia dyscyplinowania są wypracowane zazwyczaj przez wychowawców bez udziału młodzieży. Ukryty program bursy zakłada natomiast często, że dojrzały wychowanek powinien akceptować zalecenia, które przecież stworzone są dla jego dobra (Witkowski, 2014, s. 24).

Zaznaczyć należy, że za sprawą rzeczy tworzą się wyraźne połączenia (relacje) między mieszkańcami bursy a niektórymi wychowawcami, innymi wychowankami czy dyrekcją. To, co dla wychowawców jest łamaniem postanowień regulaminu, dla młodzieży może być niezwykłą okazją do integracji, ale także do okazania własnego zdania, niezgody i braku akceptacji na zastaną rzeczywistość, wyrażenia siebie i tworzenia własnej osobowości. To świadome wyrażanie oporu natomiast, jako reakcja na doświadczanie opresji, świadczy o posiadaniu przez młodzież aspiracji emancypacyjnych (Czerepaniak-Walczak, 2006, s. 142), które, poparte dążeniem do zmiany, przyjęcia nowych rozwiązań, mogących znieść opresję, może przyczynić się do rozwinięcia kompetencji emancypacyjnych (s. 130-143).

Przyjęcie perspektyw pedagogiki rzeczy i spojrzenie na rzeczy w regulaminach burs nie tylko jako elementy wyposażenia poszczególnych pokoi, 
ale również jako nośniki wartości symbolicznej, pozwala dostrzec szeroki kontekst procesów wychowawczych odbywających się w bursach szkolnych. Biorąc pod uwagę znaczący wymiar i różnorodne konteksty, w jakich rzeczy występują w regulaminach burs, warto podjąć refleksję nad ich uczestnictwem $w$ procesach wychowawczych, w tym relacjach władzy, zniewolenia, czy oporu.

\section{BIBLIOGRAFIA}

Babicka-Wirkus, A. (2015). Uczeń (nie) biega i (nie) krzyczy. Rytuały oporu jako przejaw autoekspresji młodzieży. Kraków: Wydawnictwo Naukowe Impuls.

Bilińska-Suchanek, E. (2006). Obraz szkoły w perspektywie paradygmatu oporu. W: E. Bilińska-Suchanek (red.), Opór w edukacji - aspekty teoretyczne i praktyczne. Słupsk: Wydawnictwo Naukowe Akademii Pomorskiej w Słupsku.

Brągiel, J. (1982). Społeczno-pedagogiczne funkcje internatów szkolnych. Opole: Wyższa Szkoła Pedagogiczna w Opolu.

Chutorański, M., Makowska, A. (2016). Pedagogika rzeczy (nie tylko) konsumowanych. $P a-$ rezja, 1 (5).

Chutorański, M., Makowska, A. (red.) (2019). Rzeczy, kultura, edukacja. Szczecin: Wydawnictwo Naukowe Uniwersytetu Szczecińskiego.

Czerepaniak-Walczak, M. (2006). Pedagogika emancypacyjna. Gdańsk: Gdańskie Wydawnictwo Psychologiczne.

Erikson, E.H. (2004). Tożsamość a cykl życia. Poznań: Wydawnictwo Zysk i S-ka.

Kowalik, K. (1975). Wychowanie w internacie. Warszawa: Wydawnictwa Szkolne i Pedagogiczne.

Kuratorium Oświaty w Szczecinie, Wykaz szkół i placówek, http://www.kuratorium.szczecin. pl/zalaczniki/wykaz_szkol.xls [dostęp online: 31.03.2017].

Makowski, A. (1988). Wychowanie innowacyjne w internacie. Poradnik. Warszawa: Instytut Wydawniczy Związków Zawodowych.

Marek, L. (2009). Ku odpowiedzialności wstudiowaniu pedagogiki. Toruń: Wydawnictwo Adam Marszałek.

McLaren, P. (1999). Schooling as a Ritual Performance. Toward a Political Economy of Educational Symbols and Gestures. New York: Rowman \& Littlefield Publishers.

Okrasa, M. (2017). Bursy i internaty szkolne w województwie lubelskim w latach 1918-1998. Lublin: Wydawnictwo UMCS.

Okrasa, M. (2005). Pensja SS. Wizytek funkcjonująca w XIX wieku w Lublinie oraz Działalność Towarzystwa Burs i Stypendiów w województwie lubelskim. W: Cz. Kępski (red.), Praca opiekuńczo-wychowawcza w szkole i innych instytucjach oświatowych (s. 79-102). Lublin: Wydawnictwo UMCS.

Organizacja pobytu uczniów wbursach i internatach szkolnych (2016). Raport NIK, LLU.430.006.2015, Nr ewid. 196/2015/P/15/o82/LLU, Warszawa, s. 4.

Pomykało, W. (red.) (1996). Encyklopedia pedagogiczna. Warszawa: Fundacja Innowacja.

Powszechna Deklaracja Praw Człowieka, https://amnesty.org.pl/wp-content/uploads/2016/o4/ Powszechna_Deklaracja_Praw_Czlowieka.pdf [dostęp online: 19.11.2017].

Raport NIK (2016). Organizacja pobytu uczniów w bursach i internatach szkolnych. LLU.430.006.2015, Nr ewid. 196/2015/P/15/o82/LLU, Warszawa.

Regulamin Bursy Szkolnej nr 2, http://www.13lo.szczecin.pl/bursa/regulamin.pdf (Regulamin A) [dostęp online: 31.03 .2017$]$.

Regulamin Bursy Szkolnej Integracyjnej, http://bursaintegracyjna.szczecin.pl/index.php/2011/ 03/29/historia-2/ (Regulamin C) [dostęp online: 31.03.2017]. 
Regulamin Bursy Towarzystwa Salezjańskiego, http://www.bursa-ts.szczecin.pl/strony-inne10/regulamin_bursy.htm (Regulamin B) [dostęp online: 31.03.2017].

Słownik języka polskiego PWN (2006). Warszawa: Wydawnictwo Naukowe PWN.

Słownik języka polskiego PWN, https://sjp.pwn.pl/szukaj/rzeczy.html, [dostęp online: 07.10.2017].

Węgierski, Z. (1979). Internat jako środowisko wychowawcze. Warszawa: Wydawnictwa Szkolne i Pedagogiczne.

Witkowski, L. (2014). Opór w kulturze i humanistyce. Aspekty pedagogiczne. W: E. Bilińska-Suchanek (red.), Opór w kulturze. Tradycja, edukacja, nowoczesność. Kraków: Oficyna Wydawnicza Impuls.

Zięba-Kołodziej, B. (2010). Rola internatów i burs szkolnych w budowaniu życiowej drogi młodzieży. W: Jak przezwyciężyć ubóstwo? „Księga Ubogich” A.D. 2010, X Konwencja Ruchu przeciw bezradności społecznej. Biuletyn RPO. Źródła. Warszawa: Rzecznik Praw Obywatelskich.

Zięba-Kołodziej, B. (2011). Bursy i internaty. Historia i wspótczesność. Tarnobrzeg: Wydawnictwo Państwowej Wyższej Szkoły Zawodowej.

\section{SUMMARY}

\section{Bed Made up.}

\section{Things as Instruments of Resistance in Dormitories}

In this article it is argued that things present at interschool dormitories, may be used as an expression of power over youths, or may be used by the youths as an instrument of resistance. The presence of things in interschool dormitories' regulations in Pomeranian Voivodeship and the context of using them in those documents was a source of information for us about the meanings and functions of things at interschool dormitories. However, in this article we try to look into interschool dormitories' regulations from the point of view of youths, whose presence at the dormitories is involved in the structure of power and who use things to express their resistance to the rules which they do not understand or accept.

KEY WORDS: pedagogy of things, interschool dormitories, dormitories' regulations 